http://kitaibelia.unideb.hu/

ISSN 2064-4507 (Online) • ISSN 1219-9672 (Print)

(C) Department of Botany, University of Debrecen, Hungary

24(2): 165-172.; 2019

DOI: $10.17542 /$ kit.24.165

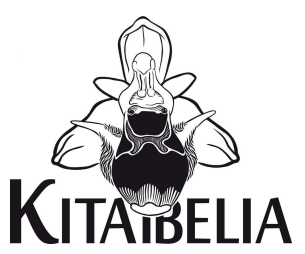

\title{
Újabb adat a magyarországi adventív flóra ismeretéhez: Polypogon viridis (Gouan) Breistr.
}

\author{
WIRTH Tamás \\ Pécsi Tudományegyetem, Ökológiai Tanszék, H-7624 Pécs, Ifjúság útja 6.; tamaswirth@gmail.com
}

A new alien species to the Hungarian flora: Polypogon viridis (Gouan) Breistr.

\begin{abstract}
Polypogon viridis (Gouan) Bresitr., a new alien species to the Hungarian flora, was detected between the years 2016-2019. Water bent ( $P$. viridis), originating from the Mediterranean basin, was recorded from several plant nurseries and outdoor flowerpots in Transdanubia, Hungary. The new Hungarian records fit into the observed phenomenon that ornamental plant trade is an important factor in the spread of this species. Morphological characterization and insertion of $P$. viridis into the Hungarian identification key are also provided in this paper. Since $P$. viridis was represented in large numbers at some of the Hungarian localities, future monitoring of its spread may be important to evaluate the invasiveness of the species in the country.
\end{abstract}

Keywords: adventive plant, ornamental plant trade, Poaceae, urban flora, water bent

Összefoglalás - Jelen dolgozat a Magyarországon korábban elő nem forduló Polypogon viridis (Gouan) Breistr. első hazai adatait közli. A Mediterráneumból származó faj a Dunántúl több pontján került elő kertészetek és faiskolák telephelyeiről, illetve kültéri virágcserépből. Jelen megfigyelések egybeesnek a külföldi tapasztalatokkal, miszerint a faj terjedésében a dísznövény kereskedelem fontos szerepet játszik. A továbbiakban megtörtént a faj morfológiai jellemzése és a hazai határozókulcsba történő beillesztése. Mivel a $P$. viridis néhány lelőhelyen nagyobb egyedszámban került elő, az inváziós képességének meghatározása szempontjából a jövőben fontos lehet a faj terjedésének monitorozása.

Kulcsszavak: adventív növény, dísznövény kereskedelem, Poaceae, urbán flóra, zöld kefefü

\section{Bevezetés}

Hazánk flórakutatásának eredményeképpen az utóbbi években megszaporodtak az ország területéről újonnan kimutatott adventív fajokról szóló tanulmányok. Ezeknek egy része vonalas létesítmények mellett terjedő (SCHMIDT et al. 2016, FEKETE et al. 2018), míg mások korábbi kultiválás eredményeképpen kivaduló (BALOGH \& MESTERHÁZY 2017) és gyakran invázióssá váló fajok (KIRÁLY et al. 2014). A magyarországi inváziós fajok között előkelő helyen szereplő (BOTTA-DUKÁT et al. 2004) pázsitfüfélék családjából számos faj megjelenését mutatták ki az utóbbi évek során. Ezek közül néhány veszélyes, potenciális inváziós növény (pl. KIRÁLY \& HOHLA 2015, KIRÁLY 2016, TÖRÖK \& ARADI 2017), míg mások alkalmilag felbukkanó vagy problémát jelenleg még nem okozó fajok (PÁL 2011, WIRTH \& LENGYEL 2014). Az utóbbi években Pécs közigazgatási területén végzett finom léptékű, szisztematikus flóratérképezés, valamint egyes dunántúli települések flórájának vizsgálata során egy hazánkban eddig ismeretlen pázsitfüfaj került elő, mely az Európában terjedő Polypogon viridis (Gouan) Breistr. fajnak bizonyult. 


\section{Anyag és módszer}

A terepi felmérések 2016-2019 között történtek. A faj azonosítása TuTin (1980) és VerLoovE (2019) munkái alapján történt. Az egyes lelőhelyek esetében a tengerszint feletti magasságok és a WGS 84 vetületben rögzített koordináták meghatározása GPS segítségével történt. A lelőhelyek felsorolása és sorrendje DövÉNYI (2010) munkáját követi. A kvadrátazonosítók a Magyarországi Flóratérképezési Program alapján kerületek megadásra (BARTHA et al. 2015). A közleményben említett taxonok tudományos nevei KIRÁlY (2009) munkáját követik. Az egyes településeken gyűjtött bizonyító példányok a Pécsi Tudományegyetem herbáriumában (JPU) kerültek elhelyezésre.

\section{Eredmények és megvitatásuk}

A Polypogon Desf. kb. 20 fajt számláló, viszonylag kicsiny nemzetség. A fajok nagy része ma már kozmopolita elterjedésű, eredendően meleg-mérsékeltövi vagy trópusi területekről származnak. A nemzetségnek eddig egy faját [P. monspeliensis (L.) Desf.] jelezték hazánkból, mint alkalmilag megjelenő adventív növényt (JÁvorkA 1925, Soó 1973, BALOGH et al. 2004). A ma már kozmopolitává vált $P$. viridis eredetileg Európában a Földközi- és a Fekete-tenger környékén őshonos (VALDÉS \& SCHOLZ 2009). Az eredeti elterjedési területén kívül kontinensünkön kimutatták még Ausztriából (HoHla 2014), Belgiumból (Verloove 2006), BoszniaHercegovinából (MASLO \& ŠARIC 2018), Nagy-Britanniából (VALDÉS \& ScHOLZ 2009) és Németországból (GROTE 2008), valamint terjedését is feljegyezték Nagy-Britannia egyes lakott területein belül (Burton 2005, PeARman \& Bennallick 2009, PescotT \& BAKER 2012).

A $P$. viridis indás, a szárcsomókon legyökerező, lazán gyepes, lágyszárú évelő. A levéllemezek laposak és hegyesek, 2-10 mm szélesek és 3-18 cm hosszúak, kopaszak, érdes tapintásúak. A nyelvecske tompa, hártyás, 1,5-5 mm hosszú. A buga felálló, hosszúkás-tojásdad, tömött, karéjos vagy az alsó felében néha ágakra oszlik, 2-15 cm hosszú és 1-4 cm széles, halványzöld vagy lilás. A füzérkék nagyszámúak, hosszúkásak, szálkátlanok, 1,7-2,2 mm hosszúak, 1-virágúak, terméséréskor a kocsánnyal együtt lehullanak. A pelyvák egyenlő hosszúságúak, a virágot elfedik, hosszúkás-kerekdedek, háti oldalukon végig apró fogaktól érdesek, 1-erűek. A külső toklász kb. fele olyan hosszú mint a pelyvák, széles kerekded, gyengén 5-erű. A belső toklász kb. olyan hosszú, mint a külső toklász, 2-erű. A portokok 0,50,7 mm hosszúak. A szemtermés halványbarna, hosszúkás, $1 \mathrm{~mm}$ hosszú (TUTiN 1980, STACE 2010, MASLO \& ŠARIC 2018, VERLOOVE 2019) (1. ábra). A faj nemzetségbeli hovatartozása ellentmondásos: korábban az Agrostis L. nemzetségbe sorolták a toklászok morfológiája alapján, azonban a jelenleg elfogadott nézet szerint (BREISTROFFER 1963, VALDÉs \& SCHOLZ 2009) a Polypogon nemzetségbe került - pl. az egyben, a toklászokkal együtt lehulló füzérkék miatt. A faj pontos nemzetségbeli hovatartozásának megállapítására a molekuláris taxonómiai vizsgálatok adhatnak megnyugtató választ a jövőben (vö. VERLoove 2019 megjegyzéseit).

Mivel magyar neve csak a nemzetségnek (kefefü), valamint a hazánkban elő nem forduló P. maritimus Willd.-nak (tengerparti k.) és a korábban alkalmi adventív növényként kimutatott P. monspeliensis-nek (közönséges k.) van (PRISZTER 1998), ezért a tudományos fajnév alapján a „zöld kefefü” magyar név alkalmazása javasolható a $P$. viridis esetében. 


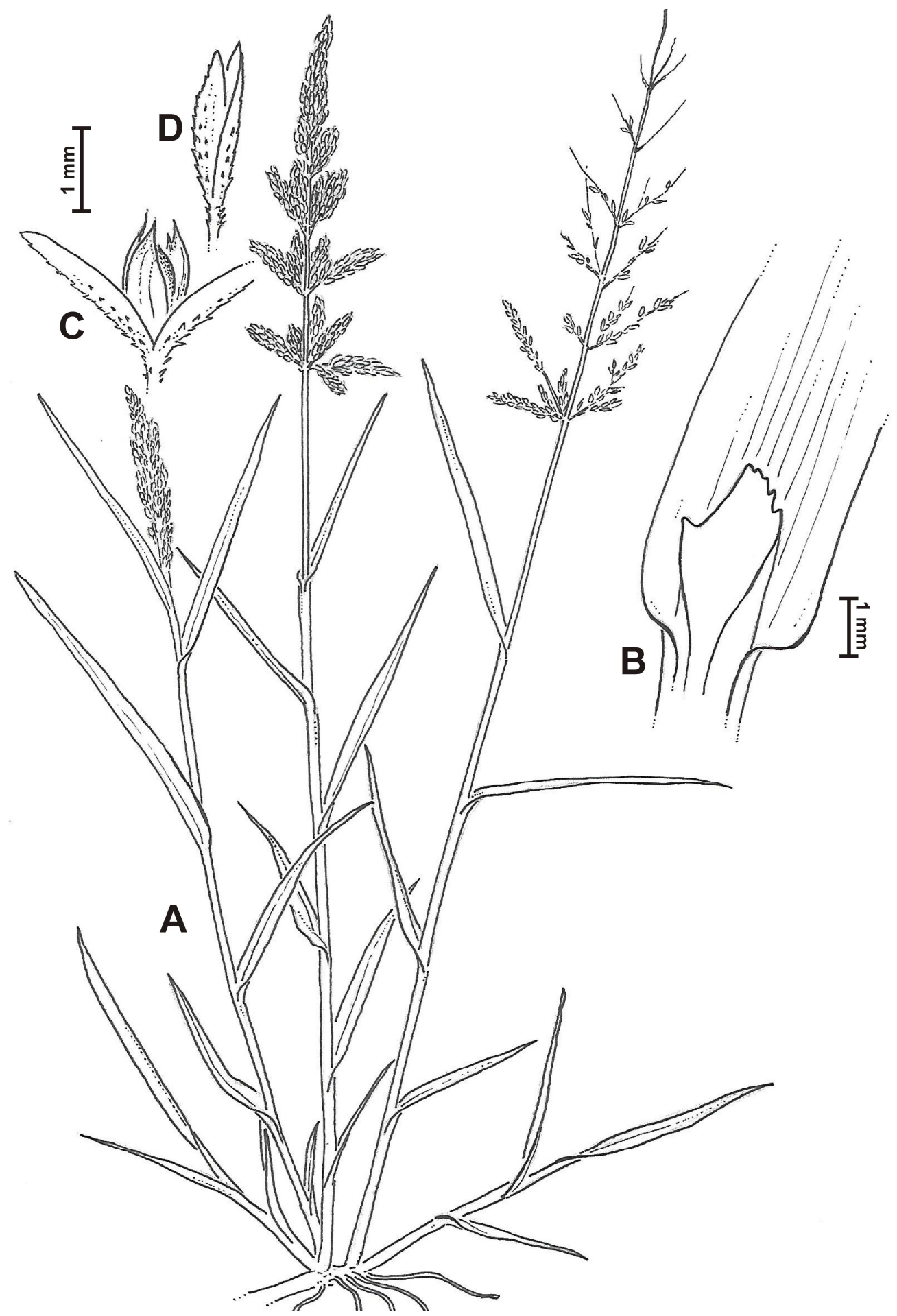

1. ábra Polypogon viridis (Gouan) Breistr. (Kóra Judit rajza)

A: habitus, B: nyelvecske, C: füzérke éretlen szemterméssel, D: érett, lehullott füzérke

Fig. 1 Polypogon viridis (Gouan) Breistr. (Drawing by Judit Kóra)

A: habit, B: ligule, C: spikelet with immature caryopsis, D: mature, disarticulated spikelet 
A Magyarországon őshonos és egyes, a $P$. viridis termőhelyeihez hasonló körülmények között is előforduló Agrostis nemzetség fajaival (főleg A. stolonifera L.) való könnyű téveszthetősége miatt javasolt a faj beillesztése a hazai határozókulcsba (PENKSZA 2009) a következők alapján:

\section{„C” kulcs - Valódi bugások}

8a Az alsó pelyva hosszabb a felsőnél. - A bugaágak virágzás után elállók vagy összezáródnak. A külső toklász rövid (2-3 mm) szálkájú v. szálkátlan. Terméséréskor a füzérke a pelyvák felett törik le, a pelyvák a bugaágakon maradók.

8b A pelyvák egyformák. - A toklászok szálkátlanok.

Agrostis

9a A buga laza, a bugaágak virágzás után visszatörnek.

Milium

9b A buga tömött, a bugaágak virágzás után el- vagy felállók. Terméséréskor a füzérkék a pelyvák alatt törnek le, ezért a teljes füzérke lehullik (a buga „lekopaszodik”). Polypogon

\section{Polypogon Desf. - Kefefü}

Indás, a szárcsomókon legyökerező, lazán gyepes, évelő lágyszárú. A buga tömött, karéjos vagy az alsó felében néha ágakra oszlik. A füzérkék terméséréskor a kocsánnyal együtt lehullanak (a buga „lekopaszodik”). A pelyvák egyenlő hosszúságúak, háti oldalukon apró fogaktól érdesek, a toklászok szálkátlanok. H: 10-60(-100) cm. He. V-VI. Adv. (Medit.). Pionír felszínek, nyírt gyepek, vízpartok. Dt (Balatonszárszó, Hidas, Kaposvár, Keszthely, Marcali, Pécs, Zamárdi), NA (Mohács). [P. semiverticillatus (Forssk.) Hyl., Agrostis semiverticillata (Forssk.) C. Chr., A. verticillata Vill., A. viridis Gouan].

$$
\text { P. viridis (Gouan) Breistr. - Zöld k. }
$$

\section{A Polypogon viridis jelenlegi hazai előfordulásai:}

Alföld: Duna menti síkság: 1.1.26 Mohácsi teraszos sík: Mohács, Pécsi út, kertészet telephelye, Catalpa bignonioides Walter cserepében néhány tő; 89 m; N45.997091², E18.670887; [0078.1]; 2019.06.14.

Dunántúli-dombság: Balaton-medence: 4.1.13 Somogyi parti sík: Balatonszárszó, kertészet telephelye, nyírt gyepben és mesterséges tavacska partján tömeges; $114 \mathrm{~m}$; N46.825510 ${ }^{\circ}$ E17.832234 ; [9173.3]; 2019.06.12. Zamárdi, Vasút utca, kertészet telephelye, nyílt felszínen néhány tő; 113 m; N46.879069º E17.942348; [9173.2]; 2019.06.12. 4.1.17 Keszthelyi-riviéra: Keszthely, Semmelweis utca, kertészet telephelye, nyílt felszíneken néhány tíz tő; 114 m; N46.772552 ${ }^{\circ}$ E17.270002; [9269.2]; 2019.06.12. Külső-Somogy: 4.2.13 Dél-Külső-Somogy: Kaposvár, a 610-es sz. út D-i oldala Kaposvár és Kaposújlak között, faiskola telephelye, nyílt felszíneken tömeges; $134 \mathrm{~m}$; N46.366431º, E17.750158; [9672.2]; 2019.06.12. Belső-Somogy: 4.3.11 Marcali-hát: Marcali, Noszlopy Gáspár utca, kertészet telephelye, nyírt gyepben néhány tő; $130 \mathrm{~m}$; N46.596221ํ. E17.406218; [9470.1]; 2019.06.12. Mecsek és Tolna-Baranyai-dombvidék: 4.4.21 Völgység: Hidas, faiskola telephelye, nyílt felszíneken tömeges; $145 \mathrm{~m}$; N46.277600 E 18.516235; [9777.1]; 2019.06.06. 4.4.31 Pécsi-síkság: Pécs, Siklósi út, a városüzemeltetési cég telephelyének udvarán, korábban dísznövények tárolására használt részen egy tő; $123 \mathrm{~m}, \mathrm{~N} 46.056557^{\circ}$, E18.229078; [9975.1]; 2016.06.09. 4.4.34 Dél-Baranyai-dombság: Pécs, Magaslati út, kültéri virágcserépben egy tő spontán; $255 \mathrm{~m}$; N46.085562 ${ }^{\circ} \mathrm{E} 18.230390^{\circ}$; [9975.1]; 2019.06.16 (2. ábra). 


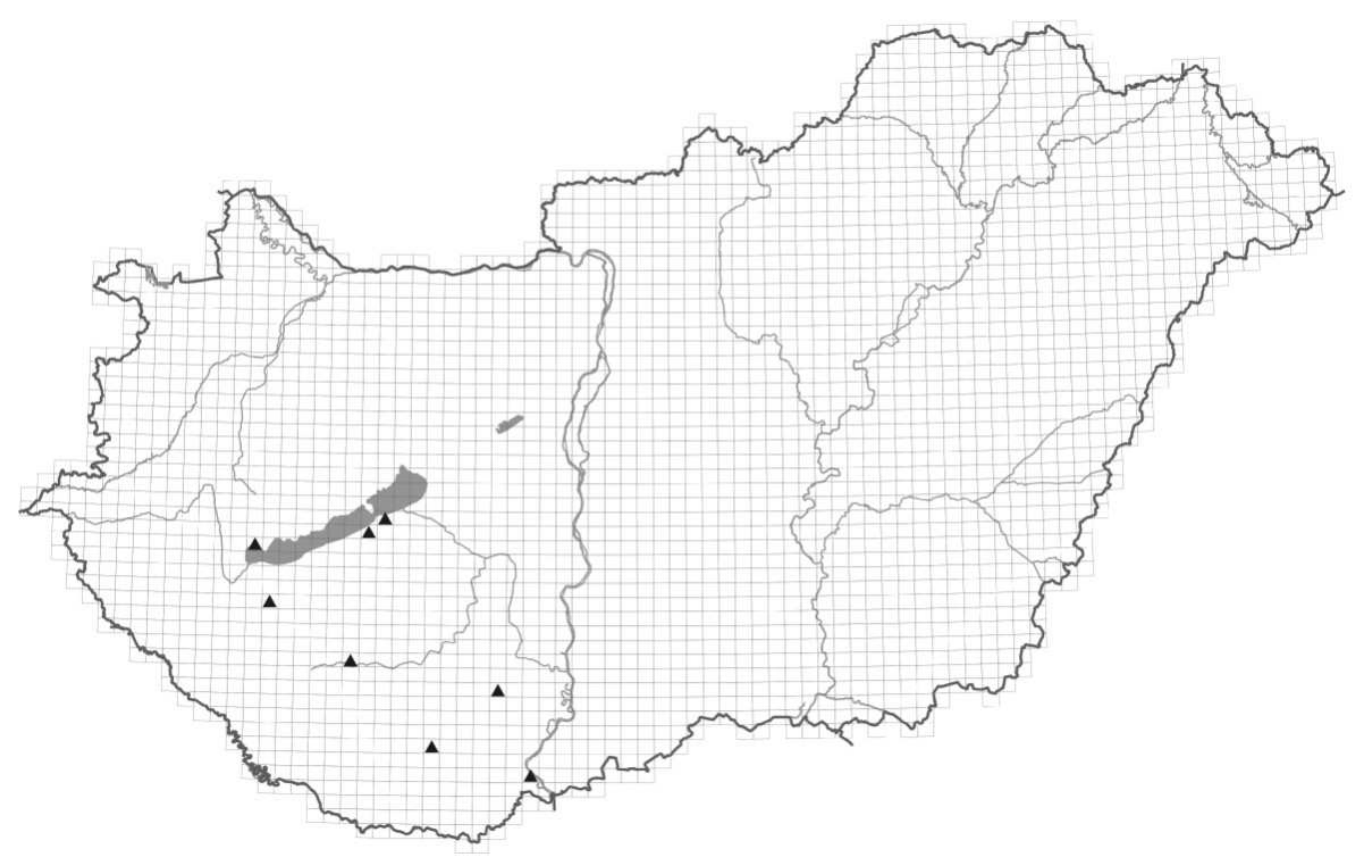

2. ábra A Polypogon viridis (Gouan) Breistr. elterjedése Magyarországon

Fig. 2 The distribution of Polypogon viridis (Gouan) Breistr. in Hungary

A P. viridis eredeti elterjedési területén általában nedves, vízközeli (tavak, vízfolyások, tengerpart) nyílt felszíneken (TUTIN 1980, MASLO \& ŠARIC 2018), másodlagosan pedig a megfelelő nedvességet biztosító zavart, bolygatott nyílt felszíneken (falak töve, járdarepedések, vízelvezető csatornák, mesterséges víztestek parti zónája) és útszegélyekben fordul elő (STACE 2010, VerLoove 2019). A hazánkban eddig előkerült állományok legnagyobb része szintén pionír jellegü, az egyéb növényzettől mechanikailag vagy kémiai szerekkel megtisztított nyílt felszíneken található (faiskolák, kertészetek, kültéri virágcserepek). A legtöbb helyen általában 1-néhány töves állományok kerültek elő, ami a faj alkalmi behurcolására utalhat - bár nem zárható ki, hogy az élőhelyeken korábban alkalmazott gyomirtások a Polypogon példányait sem kímélték -, csupán három településen (Balatonszárszó, Hidas, Kaposvár) kerületek elő nagyobb, több száz töves, meghonosodottnak tekinthető populációk. Mivel a kertészetekben és faiskolákban rendelkezésre álló körülmények (rendszeres öntözés, gyakran keletkező csupasz felszínek) kedvezők a faj számára, ezért e helyeken a folyamatos behurcolás mellett viszonylag gyorsan képes elszaporodni és nagy borítást is elérhet. Ahol a faj nem egymagában fordult elő, ott is általában az eredeti termőhelyi körülményekhez hasonló feltételeket biztosító (üde nyírt gyep, kerti tó partja), kevés kísérő fajjal (pl. Lolium perenne L., Medicago lupulina L., Oxalis corniculata L., Poa annua L., Sonchus oleraceus L., Trifolium repens L.) borított részeket foglalta el. A faj terjedésében/terjesztésében egyértelmúen nagy szerepet játszik a kertészeti kereskedelem (Hoste et al. 2009, CLEMENT 2010, BAKER \& PESCOTT 2014, HoHLA 2014), illetve például Belgiumban a kertészetek már problémás, irtandó növényeként tarják számon (VERLOove 2019). A Mediterráneumban található kertészetekből és faiskolákból az északabbi országokba importált cserepes dísznövények földlabdájában több faj viszonylag nagy távolságok megtételére képes rövid idő alatt [pl. Diplotaxis erucoides (L.) DC. Belgiumban, Hoste et al. (2009); Urtica membranacea Poir. Nagy-Britanniában, CLEMENT (2010)] a propagulumok pedig a termesztő közegben maradva és később kicsírázva évekig képesek lehetnek az utánpótlás biztosítására. 
Az utóbbi évek pécsi zöldterület fenntartási és kezelési tapasztalatai alapján elmondható, hogy megnövekedett az igény bizonyos melegkedvelő, konténeres [Chamaerops humilis L., Olea europea L., Prunus lusitanica L., Trachycarpus fortunei (Hook.) H. Wendl.] vagy akár szabadföldben is kitelelő (Lavandula spp., Pinus brutia Ten., P. halepensis Mill., P. pinaster Aiton, P. pinea L., Pistacia terebinthus L., Quercus coccifera L., Q. ilex L., stb.) dísznövények, valamint a lakosság részéről bizonyos gyümölcstermő növények (Actinidia spp., Citrus spp., Diospyros kaki L. f., Ficus carica L., Punica granatum L. és fajtáik) nagyobb mennyiségben történő kultiválására. Ezeknek a fajoknak jelenleg csak a kisebbik része származik hazai termesztésből, a legtöbbjüket külföldről (főleg Olaszországból és a Balkán-félszigetről) importálják, vagy ott gyűjtik be (az anyanövényeket legalábbis biztosan). Az importált fajokkal számos adventív növény kerülhetett hazánkba [pl. Euphorbia prostrata Aiton, E. serpens Kunth, vö. WIRTH (2018)], illetve indult terjedésnek [pl. Chenopodium glaucum L., Veronica peregrina L., vö. CSIKY et al. (2018)] az utóbbi években, és feltételezhetjük, hogy e folyamat továbbra is nagy szerepet játszik majd a közeljövőben több adventív növény terjesztésében. A zöld kefefüvel kapcsolatos további külföldi tapasztalatok - miszerint a faj az elsődleges megtelepedési helyeiről kijutott - alapján (CLEMEnT 2010, PescotT \& BAKER 2012, BAKER \& PESCOTT 2014) azt mondhatjuk, hogy a faj megjelenésére hazánk több pontján számítanunk kell.

A klímaváltozás hatásaként a következő évtizedekben várhatóan megszaporodnak majd a Magyarországot déli irányból elérő melegkedvelő, mediterrán eredetű növények (Lososová et al. 2018), továbbá bizonyos fajok szélesebb körű és gyors elterjesztésében az emberi tevékenységek (dísznövény és ültetőközeg kereskedelem) felerősítő hatása is minden bizonnyal szerepet fog játszani. Mivel jelen dolgozatban csak a Dunántúl egy bizonyos részén (a Balaton mentén, illetve annak vonalától D-re Somogy, Zala, Baranya és Tolna megyékben) és azon belül is a vizsgált települések egy speciális élőhely típusában történt a faj keresése, ezért nem kizárt, hogy a jövőben a kertészetek és faiskolák célirányos vizsgálatával az ország számos további pontján is előkerül a növény. Az elkövetkező években további vizsgálatokra lesz majd szükség annak megállapítására, hogy a $P$. viridis a jelenlegi hazai termőhelyeirôl képes lesz-e más élőhelyekre is kijutni és nem válik-e a hazai flóra problémát okozó, akár inváziós fajává. Ezzel párhuzamosan viszont szükséges felhívni a fajra a dísznövény kereskedelemben érintettek figyelmét és a növény további kertészeti terjeszkedését megakadályozandó, el kellene végezni a már felismert állományok mielőbbi és hatékony megsemmisítését.

\section{Köszönetnyilvánítás}

Az MTM Növénytár Herbáriumában (BP) való tájékozódásért Barina Zoltánnak szeretnék köszönetet mondani. A kézirat gondos lektorálásáért és a jobbító javaslatokért Sonkoly Juditnak és Korda Mártonnak tartozok köszönettel. A Polypogon viridis rajzainak elkészítéséért Kóra Juditnak vagyok hálás.

\section{Irodalom}

BaKer A. \& Pescott O. (2014): How did Polypogon viridis find itself on the streets of the British Isles? BSBI News 125: 51-52.

BALOGH L. \& Mesterházy A. (2017): Két új adventív faj előfordulása Magyarországon a buzérfélék (Rubiaceae) családjából. - Kitaibelia 22(2): 286-296.

BALOGH L., DANCZA I. \& KIRÁLY G. (2004): A magyarországi neofitonok időszerű jegyzéke, és besorolásuk inváziós szempontból. - In: MıнÁlY B. \& BoTTA-DuKÁT Z. (szerk.), Biológiai inváziók Magyarországon: Özönnövények. A KvVM Természetvédelmi Hivatalának tanulmánykötetei 9. TermészetBúVÁR Alapítvány Kiadó, Budapest, pp. 61-92. 
Bartha D., Király G., Schmidt D., TiborcZ V., Barina Z., CSiky J., JaKab G., LeSku B., Schmotzer, A. VidéKI, R. Vojткó A. \& Zólyomi Sz. (szerk.) (2015): Magyarország edényes növényfajainak elterjedési atlasza. Nyugat-magyarországi Egyetem Kiadó Sopron, 329 pp.

BotTA-DuKÁT Z., BALOGH L. \& DANCZA I. (2004): Az inváziót elősegítő tulajdonságok és tulajdonságkombinációk a hazai neofitonok jegyzékének elemzése alapján. - In: MıнÁLY B. \& BotTA-DuKÁT Z. (szerk.), Biológiai inváziók Magyarországon: Özönnövények. A KvVM Természetvédelmi Hivatalának tanulmánykötetei 9. TermészetBÚVÁR Alapítvány Kiadó, Budapest, pp. 93-110.

Breistroffer M. (1963): Flore abrégée du Diois (Drôme). - Bulletin de la Société Botanique de France 110 (Sup. 2): 42-143.

BuRTON R. (2005): Foreign grasses in London streets. - BSBI News 100: 48-49.

CSiky J., BARÁth K., CSIKynÉ RAdnai É., Deme J., Wirth T., Zurdo A. J. \& KovÁcs D. (2018): Pótlások Magyarország edényes növényfajainak elterjedési atlaszához VIII. - Kitaibelia 23(2): 238-261.

CLEMENT E. J. (2010): Weeds of container plants. - BSBI News 114: 42-43.

DövÉNYI Z. (szerk.) (2010): Magyarország kistájainak katasztere. - Budapest, MTA Földrajztudományi Kutatóintézet, 876 pp.

FEKETE R., MesterháZy A., VAlKó O. \& MolnáR V. A. (2018): A hitchhiker from the beach: the spread of the maritime halophyte Cochlearia danica along salted continental roads. - Preslia 90(1): 23-37.

GRоте S. (2008): Funde neuer und bemerkenswerter Adventivarten in Braunschweig (Niedersachsen). - Braunschweiger Geobotanische Arbeiten 9: 201-208.

HofFER-MASSARD F. (2012): Polypogon viridis (Gouan) Breitsr. : encore une nouveauté en Suisse romande. - Bulletin du Cercle vaudois de botanique 41: 99-100.

HoHLA M. (2014): Hystrix patula - neu für Österreich, sowie weitere Beiträge zur Flora von Oberösterreich, Salzburg, Steiermark und Vorarlberg. - Stapfia 101: 83-100.

Hoste I., Verloove F., NAgels C., Andriessen L. \& LAmbinon J. (2009) De adventievenflora van in België ingevoerde mediterrane containerplanten. - Dumortiera 97: 1-16.

Jávorka S. (1925): Magyar flóra (Flora hungarica). Magyarország virágos és edényes virágtalan növényeinek meghatározó kézikönyve I-II. - Studium, Budapest, 1307 pp.

KIRÁLY G. (szerk.) (2009): Új magyar füvészkönyv. Magyarország hajtásos növényei. Határozókulcsok. ANP Igazgatóság, Jósvafő, 616 pp.

KIRÁLY G. (2016): An invader at the edge of the world: Sporobolus neglectus (Poaceae) discovered at a remote locality in Hungary. - Studia Botanica Hungarica 47(2): 335-344.

Király G. \& Hohla M. (2015): New stage of the invasion: Sporobolus vaginiflorus (Poaceae) reached Hungary. - Studia Botanica Hungarica 46(2): 149-155.

KirÁLY G., TrÁVNIČEK B. \& Źíla V. (2014): Észrevétlen özönfaj a magyar flórában, az örmény szeder (Rubus armeniacus Focke). - Kitaibelia 192(2): 220-228.

Lososová Z., TichÝ L., Divíšek J., ČEplová N., Danihelka J., Dřevojan P., Fajmon K., Kalníková V., Kalusová V., Novák P., ŘEноŘEк V., Wirth T. \& ChytRÝ M. (2018): Projecting potential future shifts in species composition of European urban plant communities. - Diversity and Distributions 24(6): 765-775.

MASLO S. \& ŠARIC Š. (2018): Water Bent Polypogon viridis (Poaceae): a new grass species in the flora of Bosnia and Herzegovina. - Glasnik Hrvatskog botaničkog društva 6(2): 16-20.

PÁl R. W. (2011): Echinaria capitata (Seslerieae, Poaceae), a new grass species for the Hungarian flora. - Acta Botanica Hungarica 53(1-2): 175-180.

Pearman D. \& Bennallick I. (2009): Polypogon viridis. - BSBI News 111: 39-40.

Penksza K. (2009): Poaceae (Gramineae) - Pázsitfüvek családja. - In: KIRÁly G. (szerk.), Új magyar füvészkönyv. Magyarország hajtásos növényei. Határozókulcsok. ANP Igazgatóság, Jósvafo", pp. 498540.

Pescott O. \& BAKER A. (2012): Water bent (Polypogon viridis) new to Sheffield and South Yorkshire. Sorby Record 48: 1-3.

PRISZTER Sz. (1998): Növényneveink. - Mezőgazda Kiadó, Budapest, 549 pp.

SCHMidt D., DítĚTovÁ Z., HoRvÁth A. \& SzÛ́cs P. (2016): Coastal newcomer on motorways: the invasion of Plantago coronopus in Hungary. - Studia Botanica Hungarica 47(2): 319-344.

Soó R. (1973): A magyar flóra és vegetáció rendszertani-növényföldrajzi kézikönyve V. Akadémiai Kiadó, Budapest, $724 \mathrm{pp}$.

STACE C. (2010): New flora of the British Isles, 3rd ed. - Cambridge University Press, XXXII + 1232 pp. 
TöRÖK P. \& ARADI E. (2017): A new potentially invasive grass, sand dropseed (Sporobolus cryptandrus) discovered in sandy areas of Hungary - A call for information on new localities. - Bulletin of the Eurasian Dry Grassland Group 35: 24-25.

Tutin T. G. (1980): Polypogon Desf. - In: Tutin T. G. et al. (eds.): Flora Europaea Volume 5. Cambridge University Press, Cambridge, pp. 235-236.

Verloove F. (2006): Twee nieuwe stadsgrassen in België Bromus madritensis en Polypogon viridis. Dumortiera 90: 24-26.

WirTh T. \& LENGYel A. (2014): Két „régi-új” adventív pázsitfűfaj, a Rostraria cristata (L.) Tzvelev és a Cynosurus echinatus L. előfordulása Pécsett. - Kitaibelia 19(1): 39-42.

WIRTH T. (2018): Kiegészítések az Euphorbia prostrata és az Euphorbia serpens hazai elterjedéséhez. Kitaibelia 23(2): 267-269.

\section{Világháló oldalak}

VALDÉS B. \& Scholz H. (2009): Poaceae (pro parte majore). Euro+Med Plantbase - the information resource for Euro-Mediterranean plant diversity. http://ww2.bgbm.org/EuroPlusMed/ [accessed 20/06/2019]

Verloove, F. (2019) [Polypogon]. On: Manual of the Alien Plants of Belgium. Botanic Garden of Meise, Belgium. alienplantsbelgium.be [accessed 20/06/2019]

Beérkezett / received: 2019. 07. 02. • Elfogadva / accepted: 2019. 07. 24. 